\title{
Extracorporeal myoglobin removal in severe rhabdomyolysis with high cut-off membranes- intermittent dialysis achieves much greater clearances than continuous methods
}

\author{
Jakob Gubensek ${ }^{1,2^{*}} \mathbb{D}$, Vanja Persic $^{1,2}$, Alexander Jerman $^{1}$ and Vladimir Premru ${ }^{1}$
}

\begin{abstract}
Weidhase et al. recently published a randomized controlled trial comparing two renal replacement modalities regarding myoglobin clearance [1]. The authors found superior myoglobin clearance with a high cut-off (HCO) dialyzer running in continuous veno-venous hemodialysis (CVVHD) mode compared to a standard, high-flux dialyzer running in continuous veno-venous hemodiafiltration (CVVHDF) mode [1], which is not surprising, given the properties of $\mathrm{HCO}$ membranes. $\mathrm{HCO}$ dialyzers were first used in intermittent hemodialysis with the aim of free light chains [2] and myoglobin removal [3], but have later also been used with continuous dialysis techniques, mainly with the aim of improving clearance of inflammatory cytokines.
\end{abstract}

The authors concluded that CVVHD using HCO dialyzers could be beneficial in patients with acute kidney injury and high myoglobin levels [1]. We would like to emphasize that intermittent hemodialysis would be more suitable than continuous methods for the treatment of severe rhabdomyolysis-associated acute kidney injury (AKI). While myoglobin clearance was indeed higher in the HCO-CVVHD group, the absolute values were expectedly low, about $8-10 \mathrm{ml} / \mathrm{min}$ [1], because continuous methods have low clearances by design and cannot fully take advantage of the $\mathrm{HCO}$ membranes. On the

*Correspondence: jakob.gubensek@kclj.si

${ }^{1}$ Center for Acute and Complicated Dialysis, Department of Nephrology, University Medical Center Ljubljana, Zaloska 2, 1000 Ljubljana, Slovenia Full list of author information is available at the end of the article other hand, using $\mathrm{HCO}$ dialyzers with intermittent dialysis a much greater median myoglobin clearance of $77 \mathrm{ml} /$ min in hemodialysis [4] and $93 \mathrm{ml} / \mathrm{min}$ in hemodiafiltration mode [3] was reported. Although continuous methods compensate for low clearance by prolonged dialysis time, removal of clinically significant amounts of myoglobin is difficult to achieve. There is only one case report describing significant removal with high-dose continuous veno-venous hemofiltration (at $4 \mathrm{l} / \mathrm{h}$ of infusate) in a patient with very severe but transient rhabdomyolysis due to serotonin syndrome [5]. Such high-intensity continuous dialysis is quite cumbersome to perform and also costly, while intermittent dialysis can easily achieve effective myoglobin removal in 6-8-h sessions [3, 4], which can be extended to $12 \mathrm{~h}$ in extreme cases. The new medium cut-off membranes may prove to be an even more effective method for extracorporeal myoglobin removal because they cause less albumin loss.

In conclusion, while the role of extracorporeal myoglobin removal in severe rhabdomyolysis-associated acute kidney injury is not yet established, we suggest using $\mathrm{HCO}$ dialyzers with intermittent or extended dialysis techniques to achieve optimal myoglobin clearance in a cost-effective and time-efficient way.

Authors' contributions

$J G$ conceived the letter, and VPe, AJ and VPr revised it. All the authors read and approved the final manuscript.

Funding

Not applicable.

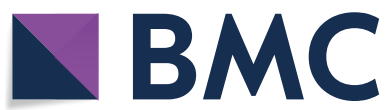

(c) The Author(s) 2021. This article is licensed under a Creative Commons Attribution 4.0 International License, which permits use, sharing, adaptation, distribution and reproduction in any medium or format, as long as you give appropriate credit to the original author(s) and the source, provide a link to the Creative Commons licence, and indicate if changes were made. The images or other third party material in this article are included in the article's Creative Commons licence, unless indicated otherwise in a credit line to the material. If material is not included in the article's Creative Commons licence and your intended use is not permitted by statutory regulation or exceeds the permitted use, you will need to obtain permission directly from the copyright holder. To view a copy of this licence, visit http://creativecommons.org/licenses/by/4.0/. The Creative Commons Public Domain Dedication waiver (http://creativecommons.org/publicdomain/zero/1.0/) applies to the data made available in this article, unless otherwise stated in a credit line to the data. 
Availability of data and materials

Not applicable.

\section{Declarations}

\section{Ethics approval and consent to participate}

Not applicable.

\section{Consent for publication}

Not applicable.

\section{Competing interests}

$J G$ reports receiving reimbursements and speaking honoraria from Baxter. Other authors declare that they have no competing interests.

\section{Author details}

1 Center for Acute and Complicated Dialysis, Department of Nephrology, University Medical Center Ljubljana, Zaloska 2, 1000 Ljubljana, Slovenia. ${ }^{2}$ Faculty of Medicine, University of Ljubljana, Vrazov trg 2, Ljubljana, Slovenia.

Received: 12 February 2021 Accepted: 4 March 2021

Published online: 09 March 2021

\section{References}

1. Weidhase L, de Fallois J, Haußig E, Kaiser T, Mende M, Petros S. Myoglobin clearance with continuous veno-venous hemodialysis using high cutoff dialyzer versus continuous veno-venous hemodiafiltration using high-flux dialyzer: a prospective randomized controlled trial. Crit Care. 2020;24(1):644.

2. Hutchison CA, Bradwell AR, Cook M, Basnayake K, Basu S, Harding S, Hattersley J, Evans ND, Chappel MJ, Sampson P, Foggensteiner L, Adu $D$, Cockwell P. Treatment of acute renal failure secondary to multiple myeloma with chemotherapy and extended high cut-off hemodialysis. Clin J Am Soc Nephrol. 2009;4(4):745-54.

3. Premru V, Kovac J, Buturovic-Ponikvar J, Ponikvar R. Some kinetic consid erations in high cut-off hemodiafiltration for acute myoglobinuric renal failure. Ther Apher Dial. 2013;17(4):396-401.

4. Heyne N, Guthoff M, Krieger J, Haap M, Häring HU. High cut-off renal replacement therapy for removal of myoglobin in severe rhabdomyolysis and acute kidney injury: a case series. Nephron Clin Pract. 2012;121(3-4):c159-64.

5. Naka T, Jones D, Baldwin I, Fealy N, Bates S, Goehl H, Morgera S, Neumayer $\mathrm{HH}$, Bellomo R. Myoglobin clearance by super high-flux hemofiltration in a case of severe rhabdomyolysis: a case report. Crit Care. 2005;9(2):R90-5.

\section{Publisher's Note}

Springer Nature remains neutral with regard to jurisdictional claims in published maps and institutional affiliations.
Ready to submit your research? Choose BMC and benefit from:

- fast, convenient online submission

- thorough peer review by experienced researchers in your field

- rapid publication on acceptance

- support for research data, including large and complex data types

- gold Open Access which fosters wider collaboration and increased citations

- maximum visibility for your research: over $100 \mathrm{M}$ website views per year

At BMC, research is always in progress.

Learn more biomedcentral.com/submissions 